\title{
3 Beta-Hydroxysteroid Dehydrogenase/Delta 5->4-Isomerase Type 1
}

National Cancer Institute

\section{Source}

National Cancer Institute. 3 Beta-Hydroxysteroid Dehydrogenase/Delta 5->4-Isomerase

Type 1. NCI Thesaurus. Code C114369.

3 beta-hydroxysteroid dehydrogenase/Delta 5->4-isomerase type 1 (373 aa, $42 \mathrm{kDa}$ ) is encoded by the human HSD3B1 gene. This protein plays a role in both the biosynthesis of hormonal steroids and the oxidative conversion of ketosteroids. 